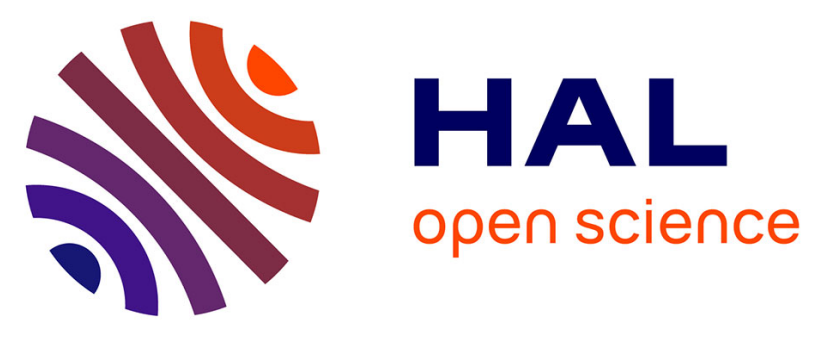

\title{
Time to revise classification of phyllodes tumors of breast? Results of a French multicentric study
}

Marie-José Adam, Sofiane Bendifallah, Négar Kalhorpour, Camille

Cohen-Steiner, Laetitia Ropars, Asma Mahmood, Chloé Rousseau, Jean

Leveque, Krystel Nyangoh Timoh, Adolphe Der Some, et al.

\section{To cite this version:}

Marie-José Adam, Sofiane Bendifallah, Négar Kalhorpour, Camille Cohen-Steiner, Laetitia Ropars, et al.. Time to revise classification of phyllodes tumors of breast? Results of a French multicentric study. EJSO - European Journal of Surgical Oncology, 2018, 44 (11), pp.1743-1749. 10.1016/j.ejso.2018.08.007 . hal-01880076

\section{HAL Id: hal-01880076}

https://hal-univ-rennes1.archives-ouvertes.fr/hal-01880076

Submitted on 8 Oct 2018

HAL is a multi-disciplinary open access archive for the deposit and dissemination of scientific research documents, whether they are published or not. The documents may come from teaching and research institutions in France or abroad, or from public or private research centers.
L'archive ouverte pluridisciplinaire HAL, est destinée au dépôt et à la diffusion de documents scientifiques de niveau recherche, publiés ou non, émanant des établissements d'enseignement et de recherche français ou étrangers, des laboratoires publics ou privés. 
Time to revise classification of phyllodes tumors of breast? results of a French multicentric study.

Marie-José Adam ${ }^{1,2}$, Sofiane Bendifallah ${ }^{3}$, Négar Kalhorpour ${ }^{3}$, Camille Cohen-Steiner ${ }^{4}$, Laetitia Ropars $^{5}$, Asma Mahmood ${ }^{6}$, Chloé Rousseau ${ }^{7}$, Jean Leveque ${ }^{1,2,8}$, Krystel Nyangoh Timoh $^{1,2}$, Adolphe Der Some ${ }^{1}$, Lobna Ouldamer ${ }^{4}$, Guillaume Legendre ${ }^{5}$, Marcos Ballester ${ }^{3}$, Emile Darai $^{3}$, Geoffroy Canlorbe ${ }^{6}$, Vincent Lavoue ${ }^{1,2,8^{*}}$

1, Service de Gynécologie, CHU de Rennes, Hôpital sud, 16 Bd de Bulgarie, 35000 Rennes, France.

2, Service de Sénologie, CRLC Eugène Marquis, Avenue de Bataille Flandres Dunkerque, 35000 Rennes, France.

3, Service de Gynécologie, CHU de Tenon, Assistance Publique des Hôpitaux de Paris, 4 Rue de la Chine, 75020 Paris, France.

4, Service de Gynécologie, CHU de Tours, Hôpital Bretonneau, 2 Boulevard Tonnellé, 37000 Tours, France.

5, Service de Gynécologie, CHU d'Angers, 4 Rue Larrey, 49100 Angers, France.

6, Service de Gynécologie, CHU La Pitié Salpêtrière, Assistance Publique des Hôpitaux de Paris, 47-83 Boulevard de l'Hôpital, 75013 Paris, France.

7, Service de Pharmacologie Clinique, CIC Inserm 1414, CHU de Rennes, Hôpital Pontchaillou, 2, rue Henri Le Guilloux, 35033 Rennes, France.

8, INSERM 1242, Chemistry, Oncogenesis, Stress and Signaling. Rennes, France.

*Corresponding authors: Pr Vincent Lavoué, Service de Gynécologie, CHU de Rennes,

Hôpital Sud, 16 bd de Bulgarie, 35000 Rennes, France. Mail: vincent.lavoue@chu-rennes.fr

Authors have no conflict of interest. 
Abstract:

Objective. To assess prognostic factors of recurrence of phyllodes tumors (PT) of the breast.

Methods. We performed a retrospective, multicentric cohort study, including all patients who underwent breast surgery for grade 1 (benign), 2 (borderline) or 3 (malignant) PT between 2000 and 2016 in five tertiary University hospitals, diagnosed according to World Health Organization classification.

Results. 230 patients were included: 144 (63\%), 60 (26\%) and $26(11 \%)$ with grade 1, 2 and 3 PT, respectively. Recurrence occurred in 10 (7\%), 7 (12\%) and 5 (19\%) patients with grade 1, 2 and 3 PT, respectively. In univariate analysis, moderate to severe nuclear stromal pleomorphism (HR 8.00 [95\% CI: 1.65 - 38.73], $\mathrm{p}<0.009)$ was correlated with recurrence in all groups including grade 1 (HR 14.3 [95\% CI: 1.29 - 160], p=0.031). In multivariate analysis, surgical margin >5 mm, (HR 0.20 [95\% CI: $0.06-0.63], \mathrm{p}=0.013$ ) were significantly correlated with less recurrence in all PT grades. For grade 1 PT, there was also significantly less recurrence with surgical margin >5mm, (HR 0.09 [95\% CI: 0.01 0.85], $\mathrm{p}=0.047$ ) in multivariate analysis.

Conclusion. The surgical margin should be at least $5 \mathrm{~mm}$ whatever the grade of PT. Moderate to severe nuclear stromal pleomorphism identified a subgroup of grade 1 PT with a higher rate of recurrence. This suggests that the WHO classification could be revised with the introduction of nuclear stromal pleomorphism to tailor PT management.

Key words: phyllodes breast tumor; benign; borderline; malignant; prognostic factors; surgery. 


\section{Introduction}

Phyllodes tumors (PT) of the breast are fibroepithelial tumors whose etiopathogenesis remains unclear. These are rare tumors accounting for around $0.3-1 \%$ of all primary breast tumors $(1,2)$. They mostly affect women in their fourth decade of life. The classic clinical presentation is a supple, painless mass, well limited, with rapid growth without associated axillary adenopathy. In 1982, the World Health Organisation (WHO) classification distinguished three types of PT according to five factors: stromal cellularity, stromal atypia, stromal overgrowth, mitotic count, and character of the tumor borders (3) (4) (5) (6) (7). The stromal overgrowth was defined as definition: absence of epithelial elements in one low-power microscopic field containing only stroma (according WHO 2012 classification)

The three types of PT are: grade 1 or benign tumors, grade 2 or borderline tumors, and grade 3 or malignant tumors representing $64 \%, 18 \%$ and $18 \%$ of all PT, respectively (8).

The average risk for local recurrence and metastasis have been reported as being $15 \%$ and $0.1 \%$ for grade $1 \mathrm{PT}, 17 \%$ and $0.2 \%$ for grade $2 \mathrm{PT}, 28 \%$ and $22 \%$ for grade $3 \mathrm{PT}$ (2). The recurrent tumor can be of a more aggressive histological form justifying surgical excision of all PT $(9,10)$. Some prognostic factors have been identified $(6,8,11,12)$ including: age, tumor size, grade, mitotic index, degree of cellular atypia, stromal necrosis and stromal cellularity and histologically negative margins for grade 1 PT, and margins greater than $10 \mathrm{~mm}$ for grades 2 and 3 PT for therapeutic factors. However, these prognostic factors are mainly based on old data. The largest study by Belkacemi et al (8) including 443 women with PT, dates from 1971 to 2003 prior to the WHO classification distinguishing 3 grades of PT. Moreover, PT management is based on low levels of evidence. Margin width was determined on a consensus from two studies by Spitaleri et al (2) and Kim et al (13) published in 2013. Thus, there is a need for a better determination of prognostic factors for optimal PT management.

Therefore, the main objective of the present study was to assess prognostic factors of PT recurrence based on clinical, pathological and surgical characteristics to tailor management of PT according to histological grade. 


\section{Material and methods}

\section{Patients}

This was a retrospective, multicenter cohort study. Data of women with histologically proven PT operated on between January 2000 and December 2016 were abstracted from five institutions in France with prospective maintained breast databases (Tours, Tenon, Angers, Rennes and Pitié Salpêtrière University Hospitals). The research protocol was approved by the Institutional Review Board ( $\mathrm{N}^{\circ}$ 2088222).

The inclusion criteria were grade 1, 2 or 3 PT histologically confirmed from a surgical specimen. The exclusion criteria were: breast adenofibroma, breast cancer, other fibroepithelial tumors than PT.

Clinical, surgical and pathological data were collected from the patients' medical charts. The histopathological data collected included: PT grade, tumor size (mm), stromal mitotic activity defined by the number of mitoses in high-magnification fields (less than 4 , between 4 and 9 or higher or equal to 10), stromal cell atypia (absent; moderate i.e., difficile to spot; or severe i.e., of high nuclear grade), stromal cellularity (mild, moderate, severe), stromal overgrowth (mild, moderate, severe), stromal nuclear pleomorphism (classified as mild: small nuclei, regular chromatin, few nucleoli; moderate: larger nuclei, visible but small nucleoli; or severe: significant variation of nuclei in size and shape, prominent nucleoli), stromal necrosis, and surgical margins.

\section{Histological evaluation}

All women were classified according to the 2012 WHO classification on final pathology serving as the standard. A PT was defined as a fibroepithelial tumor with the following four criteria: high stromal cellularity $(50 \%$ higher than that observed in adenofibromas), predominant stroma in the epithelial component, leaf-like projections into variably dilated elongated lumina and infiltrative margin (tumor border). The benign, 
borderline and malignant grades (i.e 1,2 and 3 grades) were defined in accordance with the 2012 WHO recommendations (4) using these criteria: infiltrating periphery, stromal cellularity (categorized as mild / moderate / severe assessed in the most cellular area, mild is defined as increase in at least $50 \%$ of the stroma in PT compared with a typical adenofibroma, moderate is defined as the presence of stromal nuclear crowding or overlapping, severe is defined as marked stromal cellularity), mitotic activity $(<5,5-9, \geq 10$ per 10 high power fields), and cellular atypia. The surgical specimens were analyzed by an expert breast pathologist.

\section{Treatment, follow-up and endpoints}

All women had undergone primary surgical treatment. Clinical follow-up consisted of physical examinations and the use of imaging techniques according to the findings. Recurrent disease was assessed by physical examination, histological findings, clinical follow-up and imaging. The diagnosis of recurrence was based on histological sampling. The date of the last recorded information corresponded to either the date of the last visit in the follow-up center, or the date of recurrence or death.

The primary endpoint was the ipsilateral recurrence of a PT during the follow-up period. The secondary endpoint was the PT grade.

Recurrence free survival (RFS) was defined as the time from the date of primary surgery to any PT recurrence and was censored at date of the last follow-up or date of death without recurrence. Overall survival (OS) was defined as time from primary surgery to death as a result of any cause.

\section{Statistical analysis}

For the descriptive analysis of population characteristics, a $\chi 2$ or Fisher test was used for the qualitative parameters, and a Kruskal-Wallis test for the quantitative parameters. Variables were considered statistically significant when $\mathrm{p}<0.05$. A Receiver Operating Characteristic 
(ROC) curve was used to define a surgical margin threshold. A univariate analysis of clinical, therapeutic and pathological recurrence risk factors on RFS by the log rank test was then performed. These results are presented by Hazard Ratio (HR) with 95\% confidence interval (CI). Variables with a $\mathrm{p}<0.20$ were included in a multivariate model, followed by a step-bystep descending selection. Survival curves were performed using the Kaplan-Meier model. 


\section{Results}

Characteristics of the population and preoperative data

Two-hundred thirty patients were included: 144 (63\%) had grade 1 PT, 60 (26\%) grade 2 PT, and $26(11 \%)$ grade 3 PT. The characteristics of the patients are shown in Table 1.

Surgery and post-operative data

The initial surgery for all PT grades consisted of enucleation (or local excision) for 38 patients (16.5\%), wide excision for 172 patients $(74.8 \%)$ and a total mastectomy for 20 $(8.7 \%)$. The surgical and pathological data are shown in Table 2. Adjuvant treatment consisted of radiotherapy for 14 patients $(6.1 \%)$, including one patient with grade 2 PT $(1.7 \%)$, and 13 patients with grade $3(50 \%)$. Chemotherapy was performed in three of the patients $(11.5 \%)$ with grade $3 \mathrm{PT}$.

\section{Follow-up}

The mean follow-up was 42.5 months ( \pm 46.8 months). During the follow-up period, 22 patients $(9.6 \%)$ experienced PT recurrence with 17 of the recurrences $(77 \%)$ occurring within the first 3 years of follow-up. Overall, the mean recurrence time was 28.7 months $( \pm 21.6$ months): 37 months ( \pm 27.6 months) for grade 1 PT; 21.1 months ( \pm 12.6 months) for grade 2 PT; and 22.6 months ( \pm 13.7 months) for grade 3 PT (Not Significant (NS)). Patterns of recurrences and treatments performed are described in Figure 1.

The recurrence rate was $7 \%(\mathrm{n}=10)$ for grade $1 \mathrm{PT}, 11.7 \%(\mathrm{n}=7)$ for grade $2 \mathrm{PT}$, and $19.2 \%$ $(\mathrm{n}=5)$ for grade 3 PT (NS). There were no deaths among the patients with grade 1 PT. The death rate was $1.7 \%(n=1)$ for grade 2 PT and $15.4 \%(n=4)$ for grade 3 PT $(p<0.001)$.

Overall, the 3-year RFS rate was 92.6\%: 95.8\%, 90.0\% and $80.8 \%$ for grade 1, 2 and 3 PT, respectively $(\mathrm{p}=0.018)$. The 10 -year RFS rates were $93.1 \%, 88.3 \%$ and $80.8 \%$ for grade 1,2 and 3 PT, respectively (NS). 
The 3-year OS rate was $100 \%, 96.2 \%$ and $96.2 \%$ for grade 1,2 and 3 PT, respectively $(\mathrm{p}=$ 0.072). The 10-year OS rate was $100 \%, 98.3 \%$ and $84.6 \%$ for grade 1,2 and 3 PT, respectively $(\mathrm{p}<0.001)$.

Prognostic factors

ROC curves were used to assess optimal surgical margins to prevent or decrease recurrence rate (Figure S1 - supplementary data). For grade $1 \mathrm{PT}$, a surgical margin value of $1 \mathrm{~mm}$ had a sensitivity, specificity, positive predictive value (PPV) and negative predictive value (NPV) of $41.0 \%, 90.4 \%, 22.2 \%$ and $91.8 \%$, respectively; a surgical margin value of $5 \mathrm{~mm}$ had a sensitivity, specificity, PPV and NPV of $90.0 \%, 26.8 \%, 8.8 \%$ and $97.1 \%$, respectively; and a surgical margin value of $10 \mathrm{~mm}$ had a sensitivity, specificity, PPV and NPV of 90\%, 24.4\%, $8.6 \%$ and $96.9 \%$, respectively. For grade $2 \mathrm{PT}$, a surgical margin value of $1 \mathrm{~mm}$ had a sensitivity, specificity, PPV and NPV of $28.6 \%, 92.3 \%, 33.3 \%$ and $90.6 \%$, respectively; a surgical margin value of $5 \mathrm{~mm}$ had a sensitivity, specificity, PPV and NPV of $42.9 \%, 53.8 \%$, $11.1 \%$ and $87.5 \%$, respectively; and a surgical margin value of $10 \mathrm{~mm}$ had a sensitivity, specificity, PPV and NPV of $42.8 \%, 47.2 \%, 9.7 \%$ and $13.8 \%$, respectively.

For grade 3 PT, we were unable to demonstrate margins with a meaningful sensitivity, specificity, PPV or NPV.

The prognostic factors of recurrence for all grades of PT are described in Table 3. According to univariate survival analysis, age $>40$ years (HR 0.38 [95\% CI: 0.16-0.89], $\mathrm{p}=0.026$ ), a surgical margin of more than $1 \mathrm{~mm}(\mathrm{HR} 0.29$ [95\% CI: $0.10-0.85], \mathrm{p}=0.044)$, and a margin of more than 5mm (HR 0.31 [95\% CI: $0.11-0.90], p=0.044)$ were significantly correlated with less recurrence. As a continuous variable, surgical margin size was also significantly correlated with less recurrence (HR 0.22, [95\% CI: $0.05-0.91], p=0.036)$. A margin of more than $10 \mathrm{~mm}$ (HR 0.85 [95\% CI: $0.35-2.02$ ], $\mathrm{p}=0.706)$ was not significantly correlated with less recurrence. 
The nuclear pleomorphism of the stroma was known for 97 patients and showed that moderate to severe stromal nuclear pleomorphisms (HR 8.00 [95\% CI: $1.65-38.73$ ], p = 0.009) were correlated with more recurrence.

According to multivariate analysis, a surgical margin of more than $1 \mathrm{~mm}$ (HR 0.26 [95\% CI: $0.09-0.76$ ], $\mathrm{p}=0.013)$, and of more than $5 \mathrm{~mm}(\mathrm{HR} 0.20$ [95\% CI: $0.06-0.63], \mathrm{p}=0.013)$ were significantly correlated with less recurrence for all grades of PT.

The prognostic factors for recurrence of grade $1 \mathrm{PT}$ are described in Table 4. According to univariate survival analysis, age $>40$ years $(\mathrm{HR} 0.24$ [95\% CI: $0.06-0.92], \mathrm{p}=0.038)$ and a surgical margin of more than $5 \mathrm{~mm}$ (HR 0.09 [95\% CI: $0.01-0.85$ ], p $=0.047$ ) were significantly correlated with less recurrence. Moderate to severe stromal nuclear pleomorphisms (HR 14.3 [IC 95\%: 1.29-160], p=0.031) were significantly correlated with recurrence. A margin of more than $10 \mathrm{~mm}(\mathrm{HR} 0.25$ [95\% CI: $0.03-1.95], \mathrm{p}=0.184)$ was not significantly correlated with less recurrence. Stromal nuclear pleomorphism was known for 56 of the patients with grade 1 PT: recurrence rates were 2/49 (4\%) for patients with low stromal nuclear pleomorphism and 2/7 (28\%) for those with moderate to severe stromal nuclear pleomorphism.

In multivariate analysis, only a margin over $5 \mathrm{~mm}$ was significantly correlated with less recurrence (HR 0.09 [CI 95\%: $0.01-0.85], \mathrm{p}=0.047$ ) for patients with grade 1 PT.

In univariate survival analysis for grade 2 PT, only age $>40$ years was significantly correlated with less recurrence (HR 0.12 [95\% CI: $0.03-0.53$ ], $\mathrm{p}=0.005)$. No margin width threshold was significantly correlated with recurrence for grade 2 PT, probably due to lack of power. No factors were found to be significantly correlated with recurrence for grade 3 PT in univariate analysis, probably due to lack of power. 


\section{Discussion}

The overall PT recurrence rate was 9.6\%. Surgical margin size was found to be an independent prognostic factor of recurrence for all grades of PT, including grade 1. Furthermore, stromal nuclear pleomorphism was significantly correlated with recurrence for grade 1 PT in univariate analysis, identifying a subgroup of grade 1 PT with a similar or higher recurrence rate to grade 2 PT ( $28 \%$ vs $12 \%$, respectively).

Although we did not find a significant correlation of stromal cellularity with recurrence (as others have shown $(8,13,14)$ ), in accordance with Sawalhi (2013) we found a significant correlation between stromal nuclear pleomorphism and recurrence (15). In theory, stromal nuclear pleomorphism is defined as mild (small nuclei, regular chromatin, few nucleoli); moderate (larger nuclei, visible but small nucleoli), or severe (significant variation of nuclei in size and shape, prominent nucleoli). However, in practice, these definitions appear to vary, and no inter- or intraobserver variability data are available, which could weaken reproducibility of diagnosis. In accordance with others $(2,8,13,14)$ we found that margin status is an independent prognostic factor: the wider the margin the lower the recurrence rate (in a significant manner). Kim et al $(13)$ and others $(9,10)$ advocate only in sano surgery for grade $1 \mathrm{PT}$, in contrast to the present study which showed that a margin size of more than 5 $\mathrm{mm}$ is required for grade 1 PT (with an NPV of $97.1 \%$ for recurrence). This would suggest that optimal surgical treatment for all grades of PT requires local surgical excision with a good margin size. This wide surgical excision is important as PT tends to recur with a more severe grade, as shown in the present study and others $(15,19)$.

Some limitations of the present study deserve to be mentioned. First of all, there were some missing data (such as tumor border) and a risk of underestimating recurrence rates because of the retrospective nature of the study and the duration of the inclusion period. This, coupled with a low rate of recurrence, hampered the possibility of building a scoring system to predict 
recurrences. Another limitation is the relatively short mean follow-up of 42.5 months $( \pm 46.8$ months), versus 85 months in the Spitaleri study (2) and 106 months in the Belkacemi study (8). Thus, the use of ROC curves to find margin size threshold according recurrence could be hampered. However, local recurrences are mainly observed during the first two years of follow-up $(29,30)$ and even earlier for grade 3 PT (31-32).

\section{Conclusion}

This large retrospective study analyzing data from prospectively managed databases from five major university hospitals in France, suggests that the recurrence rate of PT is around 10\% and that nearly one third of these recurrences occur in patients with a higher grade PT conveying a poorer prognosis. Surgical margin size remains the main prognostic factor, including in patients with grade $1 \mathrm{PT}$, with a required surgical margin of over $5 \mathrm{~mm}$. Moderate to severe stromal nuclear pleomorphism identified a group of grade 1 PT patients with a higher risk of recurrence $(28 \%)$.

The authors declare that they have no conflict of interest 


\section{References}

1. Macdonald OK, Lee CM, Tward JD, Chappel CD, Gaffney DK. Malignant phyllodes tumor of the female breast: association of primary therapy with cause-specific survival from the Surveillance, Epidemiology, and End Results (SEER) program. Cancer. 2006 Nov 1;107(9):2127-33.

2. Spitaleri G, Toesca A, Botteri E, Bottiglieri L, Rotmensz N, Boselli S, et al. Breast phyllodes tumor: a review of literature and a single center retrospective series analysis. Crit Rev Oncol Hematol. 2013 Nov;88(2):427-36.

3. Tan BY, Acs G, Apple SK, Badve S, Bleiweiss IJ, Brogi E, et al. Phyllodes tumours of the breast: a consensus review. Histopathology. 2016 Jan;68(1):5-21

4. The world Health Organization Histological Typing of Breast Tumors--Second Edition. The World Organization. Am J Clin Pathol. 1982 Dec;78(6):806-16.

5. Ward RM, Evans HL. Cystosarcoma phyllodes. A clinicopathologic study of 26 cases. Cancer. 1986 Nov 15;58(10):2282-9.

6. Moffat CJ, Pinder SE, Dixon AR, Elston CW, Blamey RW, Ellis IO. Phyllodes tumours of the breast: a clinicopathological review of thirty-two cases. Histopathology. 1995 Sep;27(3):205-18.

7. Cohn-Cedermark G, Rutqvist LE, Rosendahl I, Silfverswärd C. Prognostic factors in cystosarcoma phyllodes. A clinicopathologic study of 77 patients. Cancer. 1991 Nov 1;68(9):2017-22.

8. Belkacémi Y, Bousquet G, Marsiglia H, Ray-Coquard I, Magné N, Malard Y, et al. Phyllodes tumor of the breast. Int J Radiat Oncol Biol Phys. 2008 Feb 1;70(2):492-500.

9. Tremblay-Lemay R, Hogue JC, Provencher L, Poirier B, Laberge S, Diorio C, et al. How wide should margins be for phyllodes tumors of the breast? Breast J. 2017 May;23(3):315-322.

10. Bendifallah S, Canlorbe G. [Common benign breast tumors including fibroadenoma, phyllodes tumors, and papillary lesions: Guidelines]. J Gynecol Obstet Biol Reprod (Paris). 2015 Dec;44(10):1017-29.

11. Bennett IC, Khan A, De Freitas R, Chaudary MA, Millis RR. Phyllodes tumours: a clinicopathological review of 30 cases. Aust N Z J Surg. 1992 Aug;62(8):628-33.

12. Parker SJ, Harries SA. Phyllodes tumours. Postgrad Med J. 2001 Jul;77(909):428-35.

13. Kim S, Kim J-Y, Kim DH, Jung WH, Koo JS. Analysis of phyllodes tumor recurrence according to the histologic grade. Breast Cancer Res Treat. 2013 Oct;141(3):353-63.

14. Tan P-H, Jayabaskar T, Chuah K-L, Lee H-Y, Tan Y, Hilmy M, et al. Phyllodes tumors of the breast: the role of pathologic parameters. Am J Clin Pathol. 2005 Apr;123(4):529-40.

15. Sawalhi S, Al-Shatti M. Phyllodes tumor of the breast: a retrospective study of the impact of histopathological factors in local recurrence and distant metastasis. Ann Saudi Med. 2013 Apr;33(2):162-8.

16. Chua CL, Thomas A. Cystosarcoma phyllodes tumors. Surg Gynecol Obstet. 1988 Apr;166(4):302-6.

17. Briggs RM, Walters M, Rosenthal D. Cystosarcoma phylloides in adolescent female patients. Am J Surg. 1983 Dec;146(6):712-4.

18. Chen W-H, Cheng S-P, Tzen C-Y, Yang T-L, Jeng K-S, Liu C-L, et al. Surgical treatment of phyllodes tumors of the breast: retrospective review of 172 cases. J Surg Oncol. 2005 Sep 1;91(3):185-94.

19. Guillot E, Couturaud B, Reyal F, Curnier A, Ravinet J, Laé M, et al. Management of phyllodes breast tumors. Breast J. 2011 Apr;17(2):129-37.

20. Tse GMK, Lee CS, Kung FYL, Scolyer RA, Law BKB, Lau T, et al. Hormonal receptors expression in epithelial cells of mammary phyllodes tumors correlates with 
pathologic grade of the tumor: a multicenter study of 143 cases. Am J Clin Pathol. 2002 Oct;118(4):522-6.

21. Tse GMK, Lui PCW, Vong JSL, Lau K-M, Putti TC, Karim R, et al. Increased epidermal growth factor receptor (EGFR) expression in malignant mammary phyllodes tumors. Breast Cancer Res Treat. 2009 Apr;114(3):441-8.

22. Suo Z, Nesland JM. Phyllodes tumor of the breast: EGFR family expression and relation to clinicopathological features. Ultrastruct Pathol. 2000 Dec;24(6):371-81.

23. Kamitani T, Matsuo Y, Yabuuchi H, Fujita N, Nagao M, Kawanami S, et al. Differentiation between benign phyllodes tumors and fibroadenomas of the breast on MR imaging. Eur J Radiol. 2014 Aug;83(8):1344-9.

24. Tan $\mathrm{H}$, Zhang $\mathrm{S}$, Liu H, Peng W, Li R, Gu Y, et al. Imaging findings in phyllodes tumors of the breast. Eur J Radiol. 2012 Jan;81(1):e62-69.

25. Zhang Y, Kleer CG. Phyllodes Tumor of the Breast: Histopathologic Features, Differential Diagnosis, and Molecular/Genetic Updates. Arch Pathol Lab Med. 2016 Jun 30;140(7):665-71.

26. Lawton TJ, Acs G, Argani P, Farshid G, Gilcrease M, Goldstein N, et al. Interobserver variability by pathologists in the distinction between cellular fibroadenomas and phyllodes tumors. Int J Surg Pathol. 2014 Dec;22(8):695-8.

27. Jacklin RK, Ridgway PF, Ziprin P, Healy V, Hadjiminas D, Darzi A. Optimising preoperative diagnosis in phyllodes tumour of the breast. J Clin Pathol. 2006 May;59(5):4549.

28. Acar T, Tarcan E, Hacıyanlı M, Kamer E, Peşkersoy M, Yiğit S, et al. How to approach phyllodes tumors of the breast? Ulus Cerrahi Derg. 2015;31(4):197-201.

29. Zurrida S, Bartoli C, Galimberti V, Squicciarini P, Delledonne V, Veronesi P, et al. Which therapy for unexpected phyllode tumour of the breast? Eur J Cancer Oxf Engl 1990. 1992;28(2-3):654-7.

30. Reinfuss M, Mituś J, Duda K, Stelmach A, Ryś J, Smolak K. The treatment and prognosis of patients with phyllodes tumor of the breast: an analysis of 170 cases. Cancer. 1996 Mar 1;77(5):910-6.

31. Telli ML, Horst KC, Guardino AE, Dirbas FM, Carlson RW. Phyllodes tumors of the breast: natural history, diagnosis, and treatment. J Natl Compr Cancer Netw JNCCN. 2007 Mar;5(3):324-30.

32. Grabowski J, Salzstein SL, Sadler GR, Blair SL. Malignant phyllodes tumors: a review of 752 cases. Am Surg. 2007 Oct;73(10):967-9. 
Table 1. Preoperative characteristics of patients

\begin{tabular}{|c|c|c|c|c|c|}
\hline Data & $\begin{array}{r}\text { All PT } \\
n=230\end{array}$ & $\begin{array}{c}\text { PT } \\
\text { Grade 1 } \\
\text { n=144 }\end{array}$ & $\begin{array}{c}\text { PT } \\
\text { Grade } 2 \\
\mathbf{n}=60\end{array}$ & $\begin{array}{c}\text { PT } \\
\text { Grade } 3 \\
\mathbf{n}=\mathbf{2 6}\end{array}$ & p value \\
\hline Age (mean +/- SD) & $47.2 \pm 14.1$ & $44.3 \pm 12.5$ & $53.2 \pm 16.0$ & $49.6 \pm 13.7$ & $<0.001$ \\
\hline (range) & $(16-95)$ & $(16,83)$ & $(17,95)$ & $(26,80)$ & \\
\hline Parity (mean +/- SD) & $1.7 \pm 1.5$ & $1.6 \pm 1.4$ & $1.7 \pm 1.5$ & $2.3 \pm 2.0$ & 0.240 \\
\hline$\leq 1$ & $102(44.3 \%)$ & $67(46.5 \%)$ & $27(45.0 \%)$ & $8(30.8 \%)$ & 0.328 \\
\hline$\geq 2$ & $128(55.7 \%)$ & $77(53.5 \%)$ & $33(55.0 \%)$ & $18(69.2 \%)$ & \\
\hline Contraception & $65(45.1 \%)$ & $51(48.6 \%)$ & $11(44.0 \%)$ & $3(21.4 \%)$ & 0.158 \\
\hline Menopause & $85(37.0 \%)$ & $39(27.1 \%)$ & $34(56.7 \%)$ & $12(46.2 \%)$ & $<0.001$ \\
\hline Hormonal Replacement Therapy & $21(9.1 \%)$ & $12(8.3 \%)$ & $8(13.3 \%)$ & $1(3.8 \%)$ & 0.331 \\
\hline Smoking & $27(13.2 \%)$ & $21(16.0 \%)$ & $3(5.8 \%)$ & $3(13.6 \%)$ & 0.198 \\
\hline Breast adenofibroma history & $70(30.4 \%)$ & $49(34.0 \%)$ & $13(21.7 \%)$ & $8(30.8 \%)$ & 0.217 \\
\hline PT history & $2(0.9 \%)$ & $1(0.7 \%)$ & $0(0.0 \%)$ & $1(3.8 \%)$ & 0.295 \\
\hline Breast cancer history & $6(2.6 \%)$ & $1(0.7 \%)$ & $4(6.7 \%)$ & $1(3.8 \%)$ & 0.044 \\
\hline PT family history & $1(0.4 \%)$ & $1(0.7 \%)$ & $0(0.0 \%)$ & $0(0.0 \%)$ & 1 \\
\hline Pregnancy (at diagnosis) & $2(0.9 \%)$ & $1(0.7 \%)$ & $1(1.7 \%)$ & $0(0.0 \%)$ & 0.609 \\
\hline Single localisation unifocal PT & $198(86.1 \%)$ & $118(81.9 \%)$ & $56(93.3 \%)$ & $24(92.3 \%)$ & 0.077 \\
\hline Duration of symptoms & & & & & 0.017 \\
\hline$<2$ months & $55(33.1 \%)$ & $30(28.3 \%)$ & $16(34.8 \%)$ & $9(64.3 \%)$ & \\
\hline $2-12$ months & $56(33.7 \%)$ & $38(35.8 \%)$ & $13(28.3 \%)$ & $5(35.7 \%)$ & \\
\hline$>12$ months & $55(33.1 \%)$ & $38(35.8 \%)$ & $17(37.0 \%)$ & $0(0.0 \%)$ & \\
\hline Pain & $42(18.3 \%)$ & $30(20.8 \%)$ & $7(11.7 \%)$ & $5(19.2 \%)$ & \\
\hline Skin changes & $10(4.3 \%)$ & $3(2.1 \%)$ & $3(5.0 \%)$ & $4(15.4 \%)$ & 0.015 \\
\hline Nipple retraction & $1(0.4 \%)$ & $0(0.0 \%)$ & $0(0.0 \%)$ & $1(3.8 \%)$ & 0.113 \\
\hline Clinical tumor size (mm, mean +/- SD) & $43.9 \pm 60.7$ & $32.6 \pm 20.8$ & $55.5 \pm 95.2$ & $80.7 \pm 88.4$ & $<0.001$ \\
\hline (range) & $(6,700)$ & $(10,150)$ & $(6,700)$ & $(20,400)$ & \\
\hline Clinical tumor size & & & & & $<0.001$ \\
\hline$<30 \mathrm{~mm}$ & $101(45.9 \%)$ & $82(59.4 \%)$ & $17(28.8 \%)$ & $2(8.7 \%)$ & \\
\hline$\geq 30 \mathrm{~mm}$ & $119(54.1 \%)$ & $56(40.6 \%)$ & $42(71.2 \%)$ & $21(91.3 \%)$ & \\
\hline Ultrasound tumor size (mean +/- SD) & $38.8+/-43.1$ & $32.8+/-21.4$ & $35.6+/-29.8$ & $86.1+/-107.8$ & 0.007 \\
\hline (range) & $(6,400)$ & $(8,130)$ & $(6,170)$ & $(11,400)$ & \\
\hline Ultrasound tumor size & & & & & 0.003 \\
\hline$<20 \mathrm{~mm}$ & $50(25.8 \%)$ & $31(26.1 \%)$ & $18(32.1 \%)$ & $1(5.3 \%)$ & \\
\hline $20-50 \mathrm{~mm}$ & $105(54.1 \%)$ & $71(59.7 \%)$ & $26(46.4 \%)$ & $8(42.1 \%)$ & \\
\hline$\geq 50 \mathrm{~mm}$ & $39(20.1 \%)$ & $17(14.3 \%)$ & $12(21.4 \%)$ & $10(52.6 \%)$ & \\
\hline
\end{tabular}


Table 2. Surgical and pathological characteristics of patients

\begin{tabular}{|c|c|c|c|c|c|}
\hline Data & $\begin{array}{c}\text { All } \\
\text { PT } \\
\mathbf{n}=\mathbf{2 3 0} \\
\end{array}$ & $\begin{array}{c}\text { PT } \\
\text { Grade 1 } \\
\mathrm{n}=144 \\
\end{array}$ & $\begin{array}{c}\text { PT } \\
\text { Grade } 2 \\
\mathbf{n}=60 \\
\end{array}$ & $\begin{array}{c}\text { PT } \\
\text { Grade } 3 \\
\mathbf{n}=\mathbf{2 6} \\
\end{array}$ & $\mathbf{p}$ \\
\hline \multicolumn{6}{|l|}{ Initial Surgery } \\
\hline Enucleation (or local excision) & $38(16.5 \%)$ & $30(20.8 \%)$ & $7(11.7 \%)$ & $1(3.8 \%)$ & $<0.001$ \\
\hline Wide excision & $172(74.8 \%)$ & $111(77.1 \%)$ & $48(80.0 \%)$ & $13(50.0 \%)$ & \\
\hline Total mastectomy & $20(8.7 \%)$ & $3(2.1 \%)$ & $5(8.3 \%)$ & $12(46.2 \%)$ & \\
\hline Histological size (mm, mean +/- SD) & $38.9 \pm 29.0$ & $30.9 \pm 21.5$ & $47.2 \pm 29.2$ & $65.7 \pm 43.7$ & $<0.001$ \\
\hline (range) & $(5,210)$ & $(5,170)$ & $(6,130)$ & $(15,210)$ & \\
\hline \multicolumn{6}{|l|}{ No. of mitoses } \\
\hline$<4$ & $143(68.8 \%)$ & $120(92 \%)$ & $20(35.7 \%)$ & $3(13.6 \%)$ & $<0.001$ \\
\hline 4 à 9 & $31(14.9 \%)$ & $10(8 \%)$ & $19(33.9 \%)$ & $2(9.1 \%)$ & \\
\hline$\geq 10$ & $34(16.3 \%)$ & $0(0.0 \%)$ & $17(30.4 \%)$ & $17(77.3 \%)$ & \\
\hline \multicolumn{6}{|l|}{ Stromal cellular atypia } \\
\hline Mild & $141(75.4 \%)$ & $112(95.7 \%)$ & $27(55.1 \%)$ & $2(9.5 \%)$ & $<0.001$ \\
\hline Moderate & $27(14.4 \%)$ & $4(3.4 \%)$ & $18(36.7 \%)$ & $5(23.8 \%)$ & \\
\hline Severe & $19(10.2 \%)$ & $1(0.9 \%)$ & $4(8.2 \%)$ & $14(66.7 \%)$ & \\
\hline \multicolumn{6}{|l|}{ Stromal cellularity } \\
\hline Mild & $45(22.7 \%)$ & $38(30.2 \%)$ & $6(12.0 \%)$ & $1(4.5 \%)$ & $<0.001$ \\
\hline Moderate & $76(38.4 \%)$ & $55(43.7 \%)$ & $19(38.0 \%)$ & $2(9.1 \%)$ & \\
\hline Severe & $77(38.9 \%)$ & $33(26.2 \%)$ & $25(50.0 \%)$ & $19(86.4 \%)$ & \\
\hline \multicolumn{6}{|l|}{ Stromal overgrowth } \\
\hline Mild & $24(29.3 \%)$ & $19(32.8 \%)$ & $5(27.8 \%)$ & $0(0.0 \%)$ & 0.002 \\
\hline Moderate & $44(53.7 \%)$ & $34(58.6 \%)$ & $9(50.0 \%)$ & $1(16.7 \%)$ & \\
\hline Severe & $14(17.1 \%)$ & $5(8.6 \%)$ & $4(22.2 \%)$ & $5(83.3 \%)$ & \\
\hline \multicolumn{6}{|l|}{ Stromal nuclear pleomorphism } \\
\hline Mild & $68(70.1 \%)$ & $49(87.5 \%)$ & $16(57.1 \%)$ & $3(23.1 \%)$ & $<0.001$ \\
\hline Moderate & $16(16.5 \%)$ & $6(10.7 \%)$ & $9(32.1 \%)$ & $1(7.7 \%)$ & \\
\hline Severe & $13(13.4 \%)$ & $1(1.8 \%)$ & $3(10.7 \%)$ & $9(69.2 \%)$ & \\
\hline \multicolumn{6}{|l|}{ Tumor necrosis } \\
\hline Yes & $11(5.1 \%)$ & $1(0.7 \%)$ & $2(3.5 \%)$ & $8(38.1 \%)$ & $<0.001$ \\
\hline No & $206(94.9 \%)$ & $138(99.3 \%)$ & $55(96.5 \%)$ & $13(61.9 \%)$ & \\
\hline Margins after first surgery (mm, mean+/- SD) & $3.7 \pm 5.4$ & $3.7 \pm 4.9$ & $3.7 \pm 5.3$ & $3.7 \pm 8.3$ & 0.198 \\
\hline (range) & $(0,40)$ & $(0,30)$ & $(0,20)$ & $(0,40)$ & \\
\hline Second surgery & $58(25.2 \%)$ & $19(13.2 \%)$ & $25(41.7 \%)$ & $14(53.8 \%)$ & $<0.001$ \\
\hline Mastectomy & $18(31.0 \%)$ & $1(5.3 \%)$ & $6(24.0 \%)$ & $11(78.6 \%)$ & $<0.001$ \\
\hline Second lumpectomy for marge status & $40(69.0 \%)$ & $18(94.7 \%)$ & $19(76.0 \%)$ & $3(21.4 \%)$ & \\
\hline Residual disease after second surgery & $7(12.1 \%)$ & $1(5.3 \%)$ & $4(16.0 \%)$ & $2(14.3 \%)$ & 0.589 \\
\hline Margins after second surgery $(\mathrm{mm}$, mean $+/$ - SD) & $6.0 \pm 7.4$ & $4.4 \pm 5.3$ & $9.1 \pm 9.6$ & $7.5 \pm 9.0$ & 0.002 \\
\hline (range) & $(0,50)$ & $(0,30)$ & $(0,50)$ & $(0,40)$ & \\
\hline
\end{tabular}


Margins after second surgery

$<1 \mathrm{~mm}$

$\begin{array}{cccc}25(11.4 \%) & 18(13.1 \%) & 6(10.2 \%) & 1(4.2 \%) \\ 116(52.7 \%) & 84(61.3 \%) & 21(35.6 \%) & 11(45.8 \%) \\ 79(35.9 \%) & 35(25.5 \%) & 32(54.2 \%) & 12(50.0 \%)\end{array}$

[1-5] mm

$79(35.9 \%) \quad 35(25.5 \%)$

$32(54.2 \%)$

0.002

$>5 \mathrm{~mm}$

$195(84.8 \%) \quad 140(97.2 \%) \quad 51(85.0 \%)$

$4(15.4 \%)$

$<0.001$

Breast conservative surgery

$35(15.2 \%)$

$4(2.8 \%)$

$9(15.0 \%)$

$22(84.6 \%)$

Abbreviations: SD standard deviation: PT: Phyllode Tumor 


\section{ACCEPTED MANUSCRIPT}

Table 3. Univariate analysis of prognostic factors of recurrence-free survival for all phyllodes tumors

\begin{tabular}{|c|c|c|c|}
\hline Data & $\mathbf{N *}$ & HR $[95 \% \mathrm{CI}]$ & $\mathbf{p}$ \\
\hline Age $\geq 40$ years & 230 & $0.38[0.16-0.89]$ & 0.026 \\
\hline Menopause & 230 & $0.46[0.18-1.18]$ & 0.106 \\
\hline Adenofibroma history & 230 & $1.09[0.44-2.67]$ & 0.855 \\
\hline Single localisation & 230 & $0.95[0.28-3.21]$ & 0.933 \\
\hline Duration of symptoms $\geq 2$ months & 166 & $1.29[0.40-4.20]$ & 0.671 \\
\hline Pain & 230 & $0.99[0.29-3.35]$ & 0.984 \\
\hline Skin changes & 230 & $0.69[0.09-5.12]$ & 0.716 \\
\hline Grade & 230 & & 0.421 \\
\hline 1 & & 1 & \\
\hline 2 & & $1.22[0.46-3.20]$ & \\
\hline 3 & & $2.07[0.70-6.15]$ & \\
\hline Clinical tumor size $(\mathrm{mm})$ & 220 & $1.09[0.97-1.21]$ & 0.143 \\
\hline Ultrasound tumor size $(\mathrm{mm})$ & 194 & $1.90[0.55-6.62]$ & 0.600 \\
\hline No. of mitoses & 208 & & 0.427 \\
\hline$<4$ & & 1 & \\
\hline 4 à 9 & & $1.28[0.35-4.68]$ & \\
\hline$\geq 10$ & & $2.07[0.69-6.16]$ & \\
\hline Stromal cellular atypia & 187 & & 0.591 \\
\hline Mild & & 1 & \\
\hline Moderate & & $0.88[0.19-3.95]$ & \\
\hline Severe & & $1.76[0.55-5.57]$ & \\
\hline Stromal cellular & 198 & & 0.589 \\
\hline Mild & & 1 & \\
\hline Moderate & & $0.76[0.18-3.19]$ & \\
\hline Severe & & $1.33[0.36-4.84]$ & \\
\hline Stromal overgrowth & 82 & & 0.804 \\
\hline Mild & & 1 & \\
\hline Moderate & & $1.51[0.16-14.60]$ & \\
\hline Severe & & $2.58[0.15-42.95]$ & \\
\hline Stromal nuclear pleomorphism & 97 & & 0.022 \\
\hline Mild & & 1 & \\
\hline Moderate & & $5.55[0.92-33.35]$ & \\
\hline Severe & & $12.89[2.09-79.61]$ & \\
\hline $\begin{array}{l}\text { Stromal nuclear pleomorphism mild vs. } \\
\text { moderate to severe }\end{array}$ & 97 & $8.00[1.65-38.73]$ & 0.009 \\
\hline Tumor necrosis & 217 & $2.22[0.49-9.94]$ & 0.298 \\
\hline $\begin{array}{l}\text { Surgery: Breast conserving surgery vs. } \\
\text { total mastectomy }\end{array}$ & 230 & $0.73[0.27-2.01]$ & 0.544 \\
\hline Surgical margin size & 220 & $0.22[0.05-0.91]$ & 0.036 \\
\hline $\begin{array}{l}\text { Surgical margin } \geq 10 \mathrm{~mm} \text { after second } \\
\text { surgery }(\mathrm{mm})\end{array}$ & 220 & $0.85[0.35-2.02]$ & 0.706 \\
\hline $\begin{array}{l}\text { Surgical margin size after second } \\
\text { surgery }(\mathrm{mm})\end{array}$ & 220 & & 0.044 \\
\hline$<1 \mathrm{~mm}$ & & 1 & \\
\hline$[1-5] \mathrm{mm}$ & & $0.29[0.10-0.85]$ & \\
\hline$>5 \mathrm{~mm}$ & & $0.31[0.11-0.90]$ & \\
\hline
\end{tabular}

HR: Hazard Ratio; * could be less than 230 patients because of missing 
Table 4. Univariate analysis of prognostic factors of recurrence-free-survival for grade 1 phyllodes tumors

\begin{tabular}{|c|c|c|c|}
\hline Data & $\mathbf{N}^{*}$ & HR $[95 \% \mathrm{CI}]$ & $\mathbf{p}$ \\
\hline Age $\geq 40$ years & 144 & $0.24[0.06-0.92]$ & $\mathbf{0 . 0 3 8}$ \\
\hline Menopause & 144 & $0.22[0.03-1.71]$ & 0.147 \\
\hline Adenofibroma history & 144 & $2.42[0.70-8.42]$ & 0.165 \\
\hline Single localisation & 144 & $0.95[0.20-4.47]$ & 0.945 \\
\hline Duration of symptoms $\geq 2$ months & 106 & $2.76[0.32-23.68]$ & 0.355 \\
\hline Pain & 144 & $0.77[0.10-6.09]$ & 0.803 \\
\hline Skin changes & 144 & $0.00[0.00-]$. & 0.994 \\
\hline Clinical tumor size $(\mathrm{mm})$ & 144 & $1.67[0.42-6.70]$ & 0.468 \\
\hline Ultrasound tumor size $(\mathrm{mm})$ & 119 & $1.26[0.15-10.30]$ & 0.977 \\
\hline No. Of mitoses & 130 & & 0.456 \\
\hline$<4$ & & 1 & \\
\hline 4 à 9 & & $0.00[0.00-]$. & \\
\hline$\geq 10$ & & [. - . .] & \\
\hline Stromal cellular atypia & 117 & & 0.995 \\
\hline Mild & & 1 & \\
\hline Moderate & & $0.00[0.00-]$. & \\
\hline Severe & & . [. - .] & \\
\hline Stromal cellular & 126 & & 0.636 \\
\hline Mild & & 1 & \\
\hline Moderate & & $0.49[0.10-2.43]$ & \\
\hline Severe & & $0.51[0.08-3.11]$ & \\
\hline Stromal nuclear pleomorphism & 56 & & 0.075 \\
\hline Mild & & 1 & \\
\hline Moderate & & $9.95[0.62-159.6]$ & \\
\hline Severe & & $29.63[1.33-662.2]$ & \\
\hline $\begin{array}{l}\text { Stromal nuclear pleomorphism, mild vs. } \\
\text { moderate to severe }\end{array}$ & 56 & $14.37[1.29-160.1]$ & $\mathbf{0 . 0 3 1}$ \\
\hline $\begin{array}{l}\text { Surgery: Breast conserving surgery vs. total } \\
\text { mastectomy }\end{array}$ & 144 & $129[0.0-]$. & 0.994 \\
\hline Surgical margins size & 138 & $0.14[0.01-1.47]$ & 0.102 \\
\hline $\begin{array}{l}\text { Surgical margins } \geq 10 \mathrm{~mm} \text { after second surgery } \\
(\mathrm{mm})\end{array}$ & 137 & $0.25[0.03-1.95]$ & 0.184 \\
\hline Surgical margins size after second surgery $(\mathrm{mm})$ & 137 & & 0.048 \\
\hline$<1 \mathrm{~mm}$ & & 1 & \\
\hline$[1-5] \mathrm{mm}$ & & $0.28[0.07-1.03]$ & \\
\hline$>5 \mathrm{~mm}$ & & $0.09[0.01-0.85]$ & \\
\hline
\end{tabular}

HR: Hazard Ratio; * could be less than 144 patients because of missing data 
Figure 1. Description of recurrences according phyllode tumor grade.

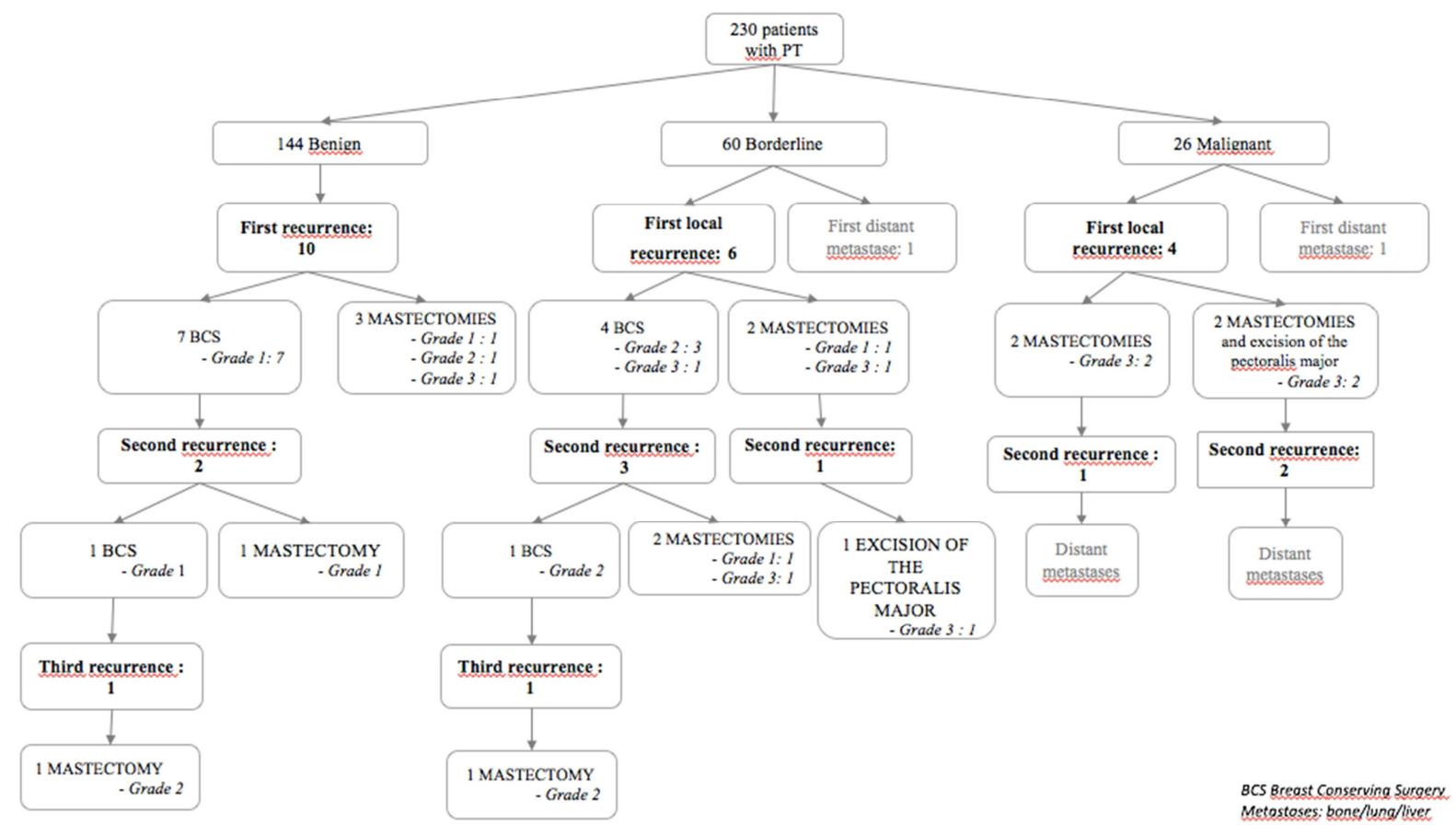

